\title{
Screening for drought tolerance and molecular variability among some sugar beet cultivars
}

\author{
Ferweez H. ${ }^{1}$ and T. Bashandy ${ }^{2}$. \\ ${ }^{1}$ Food Science and Technology Department, Faculty of Agriculture, New Valley University, New Valley, Egypt. \\ ${ }^{2}$ Genetics Department, Faculty of Agriculture, New Valley University, New Valley, Egypt.
}

\begin{abstract}
Drought is one of the significant abiotic stress factors that affect plant development and productivity. Screening and producing of more tolerant genotypes with higher yield capacity is the breeders' principal purpose. Therefore, this work was carried out to evaluate the performance of four sugar beet cultivars (Top, Hosam, Hercule and Kawamera) under water limitation. The drought stress experiment was applied based on three water regimes, $25 \%, 50 \%$ and $75 \%$ (severe, moderate and non-stress conditions, respectively) of relative water capacity (RWC). The study incorporated some productivity traits (roots and recoverable sugar yield) and quality parameters (pol\%, sugar recovery\% and quality index\%). The results showed that drought stress has a significant effect on all studied traits. Whereas, increasing of water deficiency led to decrease of the productivity traits and increasing of quality parameters. Kawamera cultivar has superior performance in all the studied traits under all three different levels of water regime. Besides that, the four cultivars were assessed by both simple sequence repeat (SSR) and inter simple sequence repeat (ISSR) molecular markers. SSR marker exhibited a higher polymorphism percentage (71.43\%) than ISSR marker (44.26\%). In addition, the mean polymorphism information content (PIC) value was higher for the SSR marker (0.25) than the ISSR marker (0.18) too. On the contrary, ISSR revealed a higher range of similarity (0.66-0.85). Moreover, the constructed dendrograms revealed that the SSR marker was able to separate the cultivars in line with according to their drought-tolerance, where the highest drought-tolerant cultivar (Kawamera) was classified alone in the main cluster. However, the superiority of Kawamera cultivar under drought stress indicated that it could be utilized in breeding programs for developing more drought-tolerant sugar beet cultivars.
\end{abstract}

Keywords: Agronomic traits; Drought; ISSR; Polymorphism; SSR; Sugar beet.

\section{Introduction}

Sugar beet (Beta vulgaris L.) is the second source of sugar worldwide after sugar cane, as well as in Egypt too (CCSC, 2010). It is widely considered a temperate-zone crop, although it is generally spreading to subtropical areas. It has a growth time that is almost half that of sugarcane, but it produces much per unit of time and uses less water (Brar et al., 2015). In Egypt, sugar beet produces about 59 $\%$ of overall sugar production (2.25 million tons per year, sugar crops and sugar production in Egypt, Sugar Crops Council Report, 2018). However, the annual sugar production in Egypt is not enough for it consumes and covered it via import from abroad. Sugar beet yield and quality are influenced by various of environmental and agronomic factors

\footnotetext{
*Corresponding author: T. Bashandy,

Email: bashandy@agr.nvu.edu.eg

Received: August 2, 2021; Accepted: August 18, 2021;

Published online : August 19, 2021.

(C) Published by South Valley University.

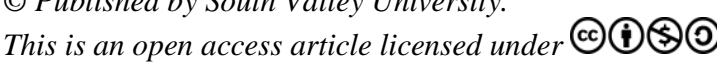

(Wu et al., 2016). Water limitation can affect the growth and activity of storage roots. Egypt suffers from water scarcity and drought, and this affects the productivity of sugar beets. To get the most productivity of sugar beet, the best cultivars for drought stress-tolerant must be chosen (Chaves et al., 2003; Ren et al., 2007; Farooq et al., 2009; Hamed and Emara, 2019).

Screening for drought tolerance and diversity among different cultivars based on morphological characterization is not enough, as these traits are more sensitive to environmental changes (Fufa et al., 2005). Therefore, the DNA molecular markers have been used as an accurate tool that are not influenced by environmental effects (Bachmann et al., 2001; Tatikonda et al., 2009). In addition, they can easily detect polymorphism that may result from nucleotide change or mutation in the genome loci (Hartl and Clark, 1997). However, among many PCR-based molecular markers, Inter Simple 
Sequence Repeat (ISSR), and microsatellites or Simple Sequence Repeat (SSR) have been widely used (Weising et al., 1992; Zietkiewicz et al., 1994; Bashandy and El-Shaieny, 2016; Bashandy et al., 2020). ISSR (dominant) markers can detect multilocus markers along the genome, by using microsatellite sequences as primers. They can amplify different sizes of DNA segments in between SSR sequences. On the other hand, SSRs are codominant markers that can detect a variable number of tandem repeats that distribute at high frequency in the nuclear DNA of most organisms (Beckmann and Weber, 1992; Reddy et al., 2002).

The main objective of this work is to evaluate four sugar beet cultivars for their performance under water limitations and asses the molecular variability among them using SSR and ISSR molecular markers.

\section{Materials and Methods}

\subsection{Plant materials and growth conditions}

Four multigerm sugar beet cultivars (Top, Hosam, Hercule and Kawamera) were used in this study. They were provided by Sugar Crops Research Institute, Agric. Res. Center, Giza, Egypt. The experiment was carried out during the 2017-2018 and 2018-2019 seasons in a private farm at Abnoub District, Assiut Governorate, Egypt. To mimic the drought stress conditions, three different water regimes based on $25 \%, 50 \%$ and $75 \%$ (severe, moderate and non-stress conditions, respectively) of relative water capacity (RWC) were applied (Hamed and Emara, 2019). Seeds of the cultivars were sown on the $5^{\text {th }}$ and $4^{\text {th }}$ October 2017 and 2018, respectively. The experimental layout was split plot in the randomized complete block design with 6 replications, water regime treatments were assigned to the main plot and the four cultivars were arranged in sub-plots. Each plot included 5 rows of $3.50 \mathrm{~m}$ length, $60 \mathrm{~cm}$ spacing and 17- 20 $\mathrm{cm}$ spacing in rows. At the harvesting time, after removing the $1^{\text {st }}$ and $5^{\text {th }}$ rows of each plot and 0.5 $\mathrm{m}$ from both ends of each row, the area of 3 central rows was harvested. The soil has texture silty clay loam (1:2.50 soil: water) with $8.00 \mathrm{pH}$. Its salinity (ECe) was $1.08 \mathrm{~m} . \mathrm{mols} / \mathrm{cm}$. To determine the RWC \%, the soil was weighed, then dried at $105^{\circ} \mathrm{C}$ before being weighed again. After all, a Kopecky cylinder $(100 \mathrm{~cm} 3)$ was used to wet the soil to its maximum holding capacity before reweighing it. Relative water capacity was measured according to the formula of $\mathrm{RWC}=100 *(\mathrm{Sn}-\mathrm{Sd}) / \mathrm{Swm}-\mathrm{Sd}$. Where, $\mathrm{Sn}=$ weight of sampled soil, $\mathrm{Sd}=$ dry soil weight and Swm= soil with hundred percent RWC weight. The different agricultural practices were applied as commercial sugar beet production. The weather temperature of the two grown years is shown in Fig. (1).

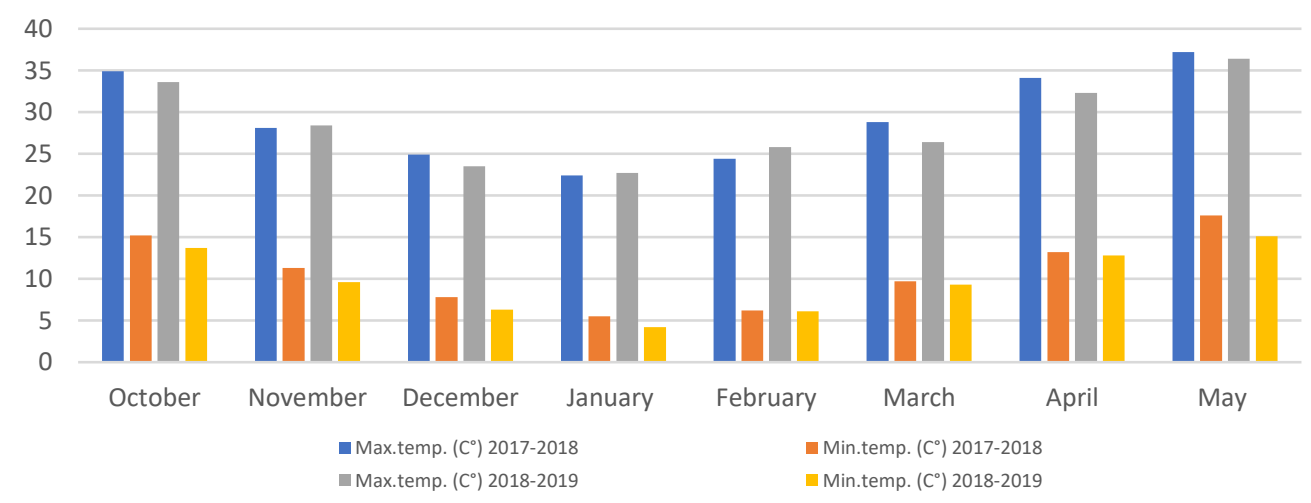

Fig. 1. Weather temperature at the private farm during carrying out experiments on sugar beet cultivars, 2017-2018 and 2018-2019 seasons (Meteorological station, Assiut, Assiut Governorate, Egypt).

At harvesting time (from sowing to harvest, it takes 195 days) a random sample of 12 healthy plants per treatment was harvested. Plants were separated into storage roots and leaves to determine the studied traits as following:
1- Root yield (ton/ hectare): Plants of all ridges from each subplot were harvested, cleaned, topped and weighed after that root yields (ton per hectare) were estimated and calculated for all experimental plots. 
2- Recoverable sugar yield per hectare $=$ root yield ton /hectare $\mathrm{x}$ recoverable sugar percentage (RS\%). 3- Sugar content or pol\%, sucrose was determined polarimetrically (ICUMSA, 2007). Sucrose concentrations for the samples obtained were expressed on a fresh weight basis.

4- Sodium, Potassium and Alpha amino nitrogen (millieq/ $100 \mathrm{~g}$ beet) were determined by using Analyzer according to A.O.A.C. (2005).

5-Recoverable sugar \% (RS\%) $=\mathrm{Pol} \%-0.29-$ $0.343(\mathrm{Na}+\mathrm{K})-0.094$ (alpha-amino-N), according to A.O.A.C. (2005), Where: Pol\% = sucrose \%, K, $\mathrm{Na}$ and a-amino $\mathrm{N}$ as millequivalent $/ 100 \mathrm{~g}$ beet.

6- Quality index (QI) was calculated using the formula of QI= Sugar recovery \% x $100 /$ pol \%.

\subsubsection{Statistical analysis}

The data was statistically examined using the analysis of variance technique by using MSTAT-C statistical software program, and Fisher's test was used. The differences among treatment means were detected by the Least significant differences (LSD) test at a 5\% level of probability and Duncan's letters (Gomez and Gomez, 1984).

\subsection{Molecular characterization}

\subsubsection{DNA extraction}

g-DNA was extracted from fresh young leaves of all cultivars using a DNA isolation kit (Favorgen
Biotech Corp. Cat.No. FAPGK001) according to the manufacturer's instructions.

\subsubsection{PCR amplification and electrophoresis}

PCR amplification of both SSR and ISSR was carried out in a reaction mixture of $25 \mu$ including 1x PCR buffer, four $\mathrm{mM} \mathrm{MgCl}_{2}, 0.2 \mathrm{mM}$ dNTPs, $2 \mu \mathrm{l}$ of $10 \mu \mathrm{M}$ primer in case of ISSR, while $2 \mu \mathrm{l}$ of $10 \mu \mathrm{M}$ each of forward and reverse primers for SSR marker, 2 units of Taq DNA polymerase and $2 \mu 1$ DNA (50 ng). In a thermal cycler (Labocon, U.K.) the reactions were carried out. Six SSR primers and Eight ISSR primers had been employed (Table 1), they were purchased from EZBiolab, USA. PCR amplifications were performed under control of program containing the preliminary denaturation for $5 \mathrm{~min}$ at $94^{\circ} \mathrm{C}$, then 38 cycles: denaturation at $94^{\circ} \mathrm{C}$ for $1 \mathrm{~min}$, annealing temperature depending on the annealing temperature of each ISSR primer or the pair of SSR primers for $1 \mathrm{~min}$, extension at $72^{\circ} \mathrm{C}$ for $2 \mathrm{~min}$, with a final elongation at $72^{\circ} \mathrm{C}$ for $7 \mathrm{~min}$. Separation of PCR products was done using $1.5 \%$ and $2.5 \%$ agarose gels for ISSR and SSR markers, respectively at $5 \mathrm{~V} / \mathrm{cm}$. The $1 \times \mathrm{TBE}$ (TrisBorate-EDTA) running buffer was used. After that, gels were stained with ethidium bromide to make them visible.

Table 1. Primers ID and sequences of both SSR and ISSR used for molecular analysis of 4 sugar beet cultivars.

\begin{tabular}{|c|c|c|c|}
\hline SSR primers & Sequence (5' to $\left.3^{\prime}\right)$ & ISSR primers & Sequence $\left(5^{\prime}\right.$ to $\left.3^{\prime}\right)$ \\
\hline Unigene 24552 & $\begin{array}{l}\text { F:AACATCTCACTCATCCTTCTTC } \\
\text { R:ATGATAGCAAACGACTAGCAG }\end{array}$ & UBC 807 & $(\mathrm{AG})_{8} \mathrm{~T}$ \\
\hline Unigene 16898 & $\begin{array}{l}\text { F:AGAACTTAGATTGTGACCTGCT } \\
\text { R:GATGGGAAGAGAGAGATTAGTG }\end{array}$ & UBC 811 & $(\mathrm{GA})_{8} \mathrm{C}$ \\
\hline Unigene 72402 & $\begin{array}{l}\text { F:TTAAGTACCAACTTCCAACAGC } \\
\text { R:GCTGGCTAACGACATAAATTC }\end{array}$ & UBC 812 & $(\mathrm{GA})_{8} \mathrm{~A}$ \\
\hline Unigene 26319 & $\begin{array}{l}\text { F:CAGAATACACTTGGTGAGATGA } \\
\text { R:TACTATGTTGTTGCTGCTGTG }\end{array}$ & UBC 815 & (CT)8G \\
\hline Unigene 48657 & $\begin{array}{l}\text { F:TAACTAAGGTTGGTGGAACA } \\
\text { R:CTCTCATTTCTCCCTATCTCTC }\end{array}$ & UBC 823 & (TC) $8 \mathrm{C}$ \\
\hline \multirow[t]{3}{*}{ Unigene14118 } & $\begin{array}{l}\text { F:AAGTCTAACACCAGAATCCAGA } \\
\text { R:AACCAGAGAGAATATGAGGATG }\end{array}$ & UBC 826 & $(\mathrm{AC}) 8 \mathrm{C}$ \\
\hline & & UBC 834 & $(\mathrm{AG}) 8 \mathrm{TT}$ \\
\hline & & UBC 846 & (CA)8GT \\
\hline
\end{tabular}


Polymorphic information content (PIC) was determined using the formula of $1-\mathrm{p}^{2}-\mathrm{q}^{2}$ (Ghislain et al., 1999), where $\mathrm{p}$ and $\mathrm{q}$ are the frequency of the present and the absent bands, respectively.

Each primer's resolving power ( $\mathrm{Rp})$ was estimated using the formula: $\mathrm{Rp}=\Sigma \mathrm{Ib}$ (band informativeness) according to Prevost and Wilkinson (1999). Whereas, the formula of $\mathrm{Ib}=1-(2 *|0.5-\mathrm{p}|)$ was used to calculate $\mathrm{Ib}$, where $\mathrm{p}$ denotes the proportion of cultivars that have the band. Marker index (MI) was estimated according to Powell et al. (1996).

\subsubsection{Data analysis}

The identified bands were given a value of 1 (present) or 0 (absent). Genetic similarity was estimated using similarity coefficient of Jaccard (Jaccard, 1908). The unweighted pair group technique with arithmetic average (UPGMA) was used to create a dendrogram according to the matrix of similarity data, cluster analysis was performed using the software computational package MVSP 3.1 .

\section{Results and Discussion}

\subsection{Effect of drought stress on the productivity traits}

Drought stress had a significant effect on the root and recoverable sugar yield, and they varied significantly among the cultivars during both seasons (Table 2). Concerning the root yield, under non-stress conditions, Kawamera had the highest value in the $1^{\text {st }}$ and $2^{\text {nd }}$ seasons (81.99 and 82.78 tons/hectare, respectively), while Hosam had the lowest values (68.24 and 69.83 tons/hectare, respectively). Also, Kawamera was superior over all the cultivars under moderate and severe stress conditions in both seasons. In the $1^{\text {st }}$ season, it scored values of 69.35 and 54.74 tons/hectare, respectively, while in the $2^{\text {nd }}$ season it had values of 70.95 and 57.31 tons/hectare, respectively. Drought stress had an antagonistic effect on the root yield of all the studied cultivars. Whereas the mean of root yield decreased with the increase of the drought level. This result is consistent with previous findings of Jozi and Zare Abyane (2015), Moosavi et al. (2017), Hamed and Emara (2019) and Khozaei et al. (2020). The reduction in root yield may be due to that drought stress can affect nutrient uptake that impairs leaves' growth and development and photosynthetic efficiency that ultimately leads to a decrease in yield (Khazaie et al., 2007).

Table 2. Mean performance of root yield and sugar yield traits of the studied 4 sugar beet cultivars under the studied 3 water regimes during the two seasons.

\begin{tabular}{|c|c|c|c|c|c|c|}
\hline \multirow[b]{2}{*}{ Cultivar } & \multicolumn{3}{|c|}{ Root yield (ton/hectare) } & \multicolumn{3}{|c|}{ Sugar yield (ton/hectare) } \\
\hline & $\begin{array}{l}\text { Normal } \\
\text { irrigation }\end{array}$ & $\begin{array}{c}\text { Moderate } \\
\text { stress }\end{array}$ & $\begin{array}{c}\text { Severe } \\
\text { stress }\end{array}$ & $\begin{array}{l}\text { Normal } \\
\text { irrigation }\end{array}$ & $\begin{array}{c}\text { Moderate } \\
\text { stress }\end{array}$ & $\begin{array}{c}\text { Severe } \\
\text { stress }\end{array}$ \\
\hline \multicolumn{7}{|c|}{$2017 / 2018$ season } \\
\hline Top & $74.42 \mathrm{c}$ & $68.86 \mathrm{a}$ & $48.22 \mathrm{c}$ & $10.88 \mathrm{~b}$ & $10.80 \mathrm{~b}$ & $7.81 \mathrm{~b}$ \\
\hline Hosam & $68.24 \mathrm{~d}$ & $60.81 \mathrm{c}$ & $45.22 \mathrm{~d}$ & $9.50 \mathrm{c}$ & $8.42 \mathrm{c}$ & $6.95 \mathrm{c}$ \\
\hline Hercule & $77.78 \mathrm{~b}$ & $63.67 \mathrm{~b}$ & $51.24 \mathrm{~b}$ & $10.72 \mathrm{~b}$ & $9.45 \mathrm{c}$ & $7.82 \mathrm{~b}$ \\
\hline Kawamera & $81.99 \mathrm{a}$ & $69.35 \mathrm{a}$ & $54.74 \mathrm{a}$ & $12.92 \mathrm{a}$ & $11.50 \mathrm{a}$ & $9.24 \mathrm{a}$ \\
\hline F value & $* *$ & $* *$ & $* *$ & $* *$ & $* *$ & $* *$ \\
\hline LSD 0.05 & 0.56 & 1.00 & 1.25 & 0.34 & 0.15 & 0.20 \\
\hline \multicolumn{7}{|c|}{$2018 / 2019$ season } \\
\hline Top & $76.30 \mathrm{c}$ & $69.62 \mathrm{~b}$ & $50.29 \mathrm{c}$ & $11.76 \mathrm{~b}$ & $10.36 \mathrm{~b}$ & $7.68 \mathrm{~b}$ \\
\hline Hosam & $69.83 \mathrm{~d}$ & $64.14 \mathrm{~d}$ & $46.81 \mathrm{~d}$ & $9.89 \mathrm{c}$ & $8.71 \mathrm{~d}$ & $6.64 \mathrm{c}$ \\
\hline Hercule & $80.63 \mathrm{~b}$ & $65.89 \mathrm{c}$ & $52.74 \mathrm{~b}$ & $11.43 \mathrm{~b}$ & $9.12 \mathrm{c}$ & $7.46 \mathrm{~b}$ \\
\hline Kawamera & $82.78 \mathrm{a}$ & $70.95 \mathrm{a}$ & $57.31 \mathrm{a}$ & $13.14 \mathrm{a}$ & $10.76 \mathrm{a}$ & $9.23 \mathrm{a}$ \\
\hline F value & $* *$ & $* *$ & $* *$ & $* *$ & $* *$ & $* *$ \\
\hline LSD 0.05 & 1.27 & 1.27 & 1.64 & 0.40 & 0.19 & 0.23 \\
\hline
\end{tabular}

** highly significant at 0.01 levels of probability; the different letters (in the same column) represent statistically significant differences between treatments $(\mathrm{p}<0.05)$.

As shown in Table (2) the sugar yield trait differed significantly among the different levels of irrigation and the cultivars in the two seasons. In the first season of evaluation, Kawamera was the best one under normal, moderate and severe stress conditions, where scored the values of $12.92,11.50$ and 9.24 tons/hectare, respectively. Hosam cultivar had the lowest values of $9.50,8.42$ and 6.95 tons/hectare, respectively. In the second season, Kawamera and Hosam cultivars had the highest and the lowest value, respectively in all applied conditions. The superiority of Kawamera cultivar 
may be due to it had the highest values of both root yield and sugar recovery $\%$. The sugar yield trait was affected by the different levels of irrigation which agrees with the results of Mahmoodi et al. (2015). Nourjou (2008) reported that the decreasing of sugar yield resulted from decreasing in irrigation amount may be attributed to translocated metabolic products from leaves to root. On the contrary, Foroozesh et al. (2012) found that this trait did not differ significantly between different irrigation levels (normal and stress).

\subsection{Effect of drought stress on the quality parameters}

The pol\% varied significantly among the cultivars under both stressed and non-stressed conditions (Table 3). In the first season of evaluation, Hosam cultivar had the lowest values of 16.10, 16.75 and $17.51 \%$ under normal, moderate and severe stress conditions, respectively. Whereas, the highest values $(17.99,18.71 \%$ and 19.05$)$ were recorded for Kawamera cultivar under normal, moderate and severe stress conditions, respectively. Moreover, Hosam and Kawamera cultivars had the lowest and the highest values, respectively in the second season.

Concerning sugar recovery $\%$ trait, under normal conditions, its values ranged from $13.78 \%$ for Hercule to $15.75 \%$ for Kawamera cultivar in the first season (Table 3). Whereas, under moderate and severe stress conditions, Kawamera cultivar had the highest values (16.58 and $16.89 \%$, respectively). In the second season, Kawamera cultivar had the highest values (15.17, 16.12 and 15.87\%) under normal, moderate and severe stress conditions, respectively.

For the quality index trait in the first season, Kawamera cultivar recorded the highest value $(87.55 \%)$ under normal conditions and high significant than other genotypes, but the differences among the other cultivars were not significant. Moreover, Kawamera cultivar had the highest values (88.60 and $88.65 \%$ ) under moderate and severe stress conditions, respectively, while Hosam produced the lowest value of $85.16 \%$ under moderate stress conditions. Whereas, in the second season the highest values (87.67 and $88.17 \%$ ) under both the normal and moderate stress conditions, respectively was also obtained by Kawamera cultivar, while Hosam cultivar had the lowest values of 84.45 and $85.75 \%$, respectively. Under severe stress, the differences among all cultivars were not significant.

Based on all the above results, drought stress had a significant effect on sugar content, sugar recovery and quality index. All these traits considerably increased as water deficiency increased. Similar findings were reported by Mahmoodi et al. (2015) and Hamed and Emara (2019).

Table 3. Mean performance of pol\%, sugar recovery $\%$ and quality index traits of the studied 4 sugar beet cultivars under the studied 3 water regimes during the two seasons.

\begin{tabular}{|c|c|c|c|c|c|c|c|c|c|}
\hline \multirow[b]{2}{*}{ Cultivar } & \multicolumn{3}{|c|}{ Pol\% } & \multicolumn{3}{|c|}{ Sugar recovery\% } & \multicolumn{3}{|c|}{ Quality index\% } \\
\hline & $\begin{array}{c}\text { Normal } \\
\text { irrigation }\end{array}$ & $\begin{array}{c}\text { Moderate } \\
\text { stress }\end{array}$ & $\begin{array}{c}\text { Severe } \\
\text { stress }\end{array}$ & $\begin{array}{l}\text { Normal } \\
\text { irrigation }\end{array}$ & $\begin{array}{c}\text { Moderate } \\
\text { stress }\end{array}$ & $\begin{array}{c}\text { Severe } \\
\text { stress }\end{array}$ & $\begin{array}{l}\text { Normal } \\
\text { irrigation }\end{array}$ & $\begin{array}{l}\text { Moderate } \\
\text { stress }\end{array}$ & $\begin{array}{c}\text { Severe } \\
\text { stress }\end{array}$ \\
\hline \multicolumn{10}{|c|}{$2017 / 2018$ season } \\
\hline Top & $17.19 \mathrm{~b}$ & $17.92 \mathrm{~b}$ & $18.58 \mathrm{~b}$ & $14.62 \mathrm{~b}$ & $15.69 \mathrm{~b}$ & $16.21 \mathrm{~b}$ & $85.03 \mathrm{~b}$ & $87.54 \mathrm{~b}$ & $87.23 \mathrm{~b}$ \\
\hline Hosam & $16.10 \mathrm{~d}$ & $16.75 \mathrm{~d}$ & $17.51 \mathrm{~d}$ & $13.92 \mathrm{c}$ & $14.34 \mathrm{~d}$ & $15.36 \mathrm{c}$ & $85.12 \mathrm{~b}$ & $85.16 \mathrm{c}$ & $86.85 \mathrm{c}$ \\
\hline Hercule & $16.60 \mathrm{c}$ & $16.92 \mathrm{c}$ & $17.77 \mathrm{c}$ & $13.78 \mathrm{c}$ & $14.84 \mathrm{c}$ & $15.26 \mathrm{c}$ & $85.11 \mathrm{~b}$ & $87.71 \mathrm{~b}$ & $86.69 \mathrm{c}$ \\
\hline Kawamera & $17.99 \mathrm{a}$ & $18.71 \mathrm{a}$ & $19.05 \mathrm{a}$ & $15.75 \mathrm{a}$ & $16.58 \mathrm{a}$ & $16.89 \mathrm{a}$ & $87.55 \mathrm{a}$ & $88.60 \mathrm{a}$ & $88.65 \mathrm{a}$ \\
\hline$F$ value & $* *$ & $* *$ & $* *$ & $* *$ & $* *$ & $* *$ & $* *$ & $* *$ & $* *$ \\
\hline LSD 0.05 & 0.26 & 0.10 & 0.16 & 0.36 & 0.14 & 0.18 & 1.08 & 0.37 & 0.36 \\
\hline \multicolumn{10}{|c|}{2018 / 2019 season } \\
\hline Top & $17.12 \mathrm{~b}$ & $17.65 \mathrm{~b}$ & $17.67 \mathrm{~b}$ & $14.89 \mathrm{~b}$ & $15.28 \mathrm{~b}$ & $15.41 \mathrm{~b}$ & $86.96 \mathrm{~b}$ & $86.55 \mathrm{~b}$ & 87.24 \\
\hline Hosam & $16.09 \mathrm{~d}$ & $16.54 \mathrm{~d}$ & $16.52 \mathrm{~d}$ & $13.58 \mathrm{~d}$ & $14.18 \mathrm{c}$ & $14.17 \mathrm{~b}$ & $84.45 \mathrm{c}$ & $85.75 \mathrm{c}$ & 85.34 \\
\hline Hercule & $16.28 \mathrm{c}$ & $16.66 \mathrm{c}$ & $16.59 \mathrm{c}$ & $14.01 \mathrm{c}$ & $14.14 \mathrm{c}$ & $14.18 \mathrm{~b}$ & $87.07 \mathrm{~b}$ & $85.96 \mathrm{c}$ & 85.47 \\
\hline Kawamera & $17.30 \mathrm{a}$ & $18.28 \mathrm{a}$ & $18.11 \mathrm{a}$ & $15.17 \mathrm{a}$ & $16.12 \mathrm{a}$ & $15.87 \mathrm{a}$ & $87.67 \mathrm{a}$ & $88.17 \mathrm{a}$ & 87.63 \\
\hline F value & $* *$ & $* *$ & $* *$ & $* *$ & $* *$ & $* *$ & $* *$ & $* *$ & ns \\
\hline LSD 0.05 & 0.13 & 0.10 & 0.04 & 0.14 & 0.14 & 0.48 & 0.36 & 0.39 & - \\
\hline
\end{tabular}

** and ${ }^{\mathrm{ns}}$ highly significant and non-significant at 0.01 and 0.05 levels of probability, respectively; the different letters (in the same column) represent statistically significant differences between treatments $(\mathrm{p}<0.05)$. 


\subsection{SSR and ISSR marker analysis}

\subsubsection{Polymorphism and variability evaluation}

To study genetic diversity and relationship between the four different cultivars of sugar beet, two types of DNA molecular markers (SSR and ISSR) were utilized. Six SSR markers and eight ISSR markers were employed in the PCR amplifications (Fig. 2). Concerning the SSR marker, the sum of detected alleles varied from one primer to another. It was fluctuated from 2 alleles for both Unigene 72402 and Unigene14118 primers to six for Unigene 24552 primer (Table 4). A total of 21 bands were generated having sizes ranged from $130 \mathrm{bp}$ to $293 \mathrm{bp}$. Truly, 15 bands were polymorphic, with $71.43 \%$ polymorphism. However, ISSR markers produced 61 fragments with sizes varied from $125 \mathrm{bp}$ to 1800 bp. Among them, 27 bands were polymorphic. Therefore, the polymorphism percentage was $44.26 \%$. additionally, UBC815 primer was able to detect a unique band at size of 460 bp that only present in Hosam cultivar (the worst cultivar for most the evaluated traits). This band may be a negative specific band associated with drought tolerance.

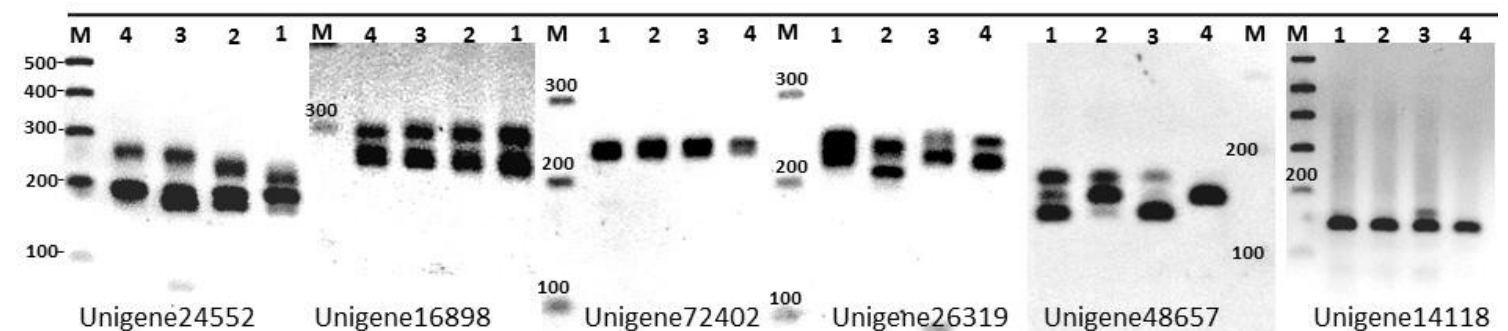

a) SSR

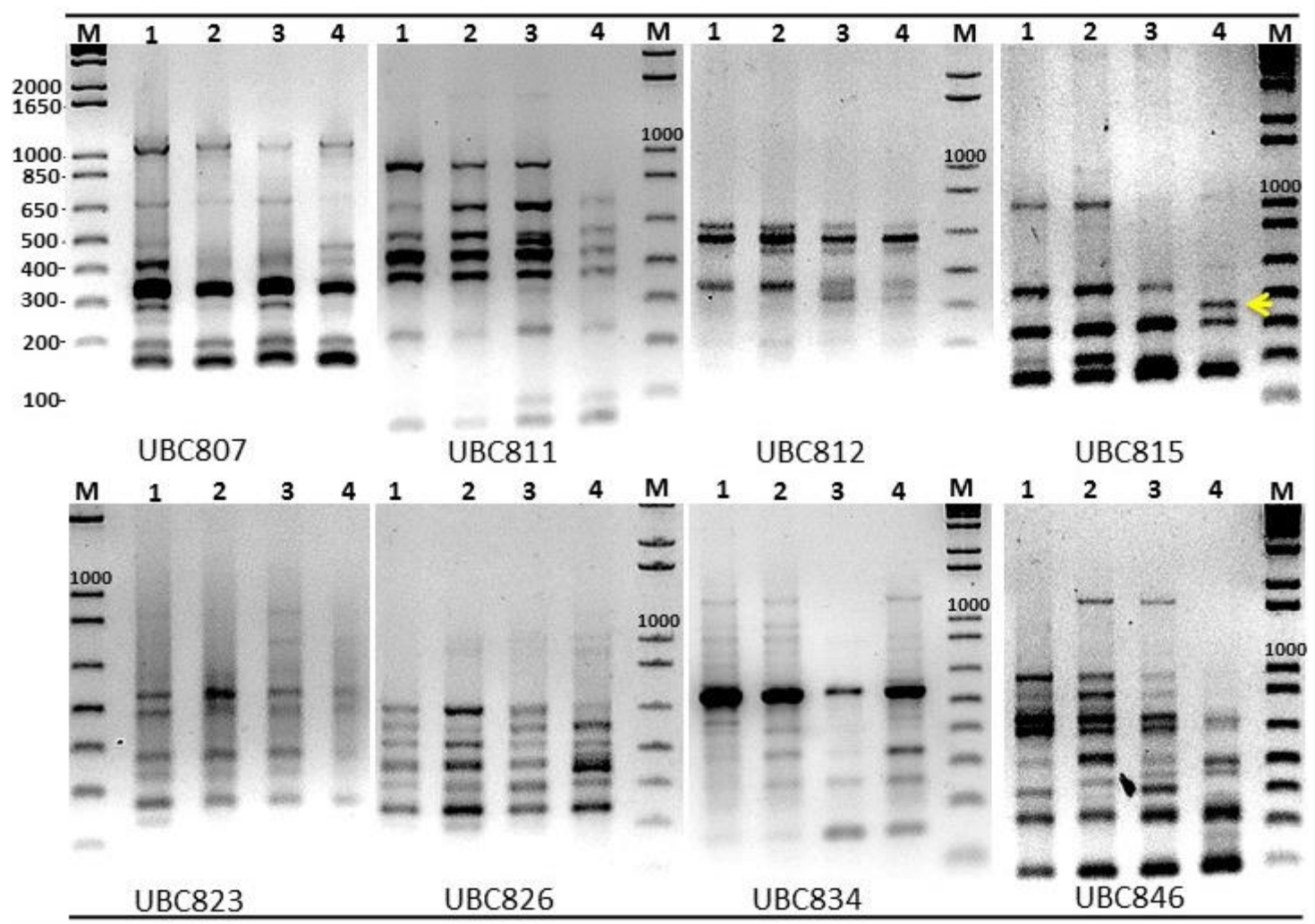

b) ISSR

Fig. 2. SSR (a) and ISSR (b) pattern in the four sugar beet cultivars. M, kbp DNA marker; 1, Top; 2, Kawamera; 3, Hercule; 4, Hosam cultivar, yellow arrow shows a negative drought tolerance associated band.

Many researchers have used SSR and ISSR markers to detect the genetic diversity in sugar beet
(Izzatullayeva et al., 2014, Abbasi et al., 2015, Taški-Ajduković et al., 2017 and Bogacheva et al., 2019). As expected, the ISSR marker showed higher 
both of average and the total number of alleles, which is in agreement with the results of Rawat $e t$ al. (2014) and Abdollahi-Mandoulakani et al. (2015). In contrast, the SSR marker detected a higher polymorphism percentage than the ISSR marker. Indeed, the level of polymorphism is reflecting the range of gene diversity, and its evaluation is based on DNA fragment length or repeats (Innan et al., 1997). Similar results were exhibited by Hamza et al. (2013), Rawat et al. (2014) and Abdollahi-Mandoulakani et al. (2015). To better testing the competence of the markers for diversity detection, the PIC value was calculated (Table 4). The PIC value for SSR markers ranged from 0.00 to 0.42 with a mean of 0.25 , but this value varied from 0.05 to 0.27 with the mean of 0.18 . The estimated PIC value was higher for SSR than the ISSR marker. Thus, the SSR marker was more discriminative than the ISSR marker because of the high allelic diversity in the SSR sequences
(Abdollahi-Mandoulakani et al., 2015). In a comparative investigation between ISSR and SSR Markers for characterization of Alfalfa populations, Abdollahi-Mandoulakani et al. (2015) revealed likewise the PIC value of SSR was higher than in ISSR marker. Furthermore, the resolving power (Rp) value was calculated to select the most distinguishable primer for the cultivars according to their genetic diversity (Table 4). In the SSR marker both Unigene 24552 and Unigene26319 primers showed the highest value (3.0), while in the ISSR marker, UBC 846 primer had the highest value (4.8). Accordingly, all these three primers in both SSR and ISSR markers had the most capability for detecting and displaying the highest allelic variations (Sharma et al., 2009). Furthermore, according to the estimated marker index (MI) values, SSR had more discriminative efficiency because SSR scored higher an average (0.88) in comparison to ISSR (0.68).

Table 4. Polymorphism (P\%), polymorphic information content value (PIC), resolving power (Rp) and marker index (MI) obtained by SSR and ISSR markers in the four tested sugar beet cultivars.

\begin{tabular}{|c|c|c|c|c|c|c|c|c|}
\hline $\begin{array}{l}\text { Primers } \\
\text { Name }\end{array}$ & $\begin{array}{c}\text { Fragments } \\
\text { size range bp }\end{array}$ & $\begin{array}{c}\text { Fragments } \\
\text { No. }\end{array}$ & $\begin{array}{c}\text { Monomorphic } \\
\text { fragments }\end{array}$ & $\begin{array}{l}\text { Polymorphic } \\
\text { fragments }\end{array}$ & $\mathrm{P} \%$ & PIC & $\mathrm{R} \mathrm{p}$ & MI \\
\hline \multicolumn{9}{|l|}{ SSR } \\
\hline Unigene24552 & $158-260$ & 6 & 1 & 5 & 83,33 & 0.33 & 3 & 1.65 \\
\hline Unigene16898 & $260-293$ & 3 & 3 & 0 & 0 & 0 & 0 & 0 \\
\hline Unigene 72402 & $225-240$ & 2 & 1 & 1 & 50 & 0.19 & 0.5 & 0.19 \\
\hline Unigene26319 & $211-250$ & 5 & 0 & 5 & 100 & 0.4 & 3 & 2 \\
\hline Unigene 48657 & $130-167$ & 3 & 0 & 3 & 100 & 0.42 & 2 & 1.26 \\
\hline Unigene14118 & $135-155$ & 2 & 1 & 1 & 50 & 0.19 & 0.5 & 0.19 \\
\hline Total & - & 21 & 6 & 15 & - & - & - & - \\
\hline Average & - & 3.5 & 1 & 2.5 & 63.89 & 0.25 & - & 0.88 \\
\hline \multicolumn{9}{|l|}{ ISSR } \\
\hline UBC 807 & $327-635$ & 7 & 6 & 1 & 14.29 & 0.05 & 0.5 & 0.1 \\
\hline UBC 811 & $145-890$ & 10 & 7 & 3 & 30 & 0.11 & 1.5 & 0.33 \\
\hline UBC 812 & $425-667$ & 5 & 3 & 2 & 40 & 0.18 & 1.5 & 0.36 \\
\hline UBC 815 & $230-980$ & 6 & 2 & 4 & 66.67 & 0.27 & 2.5 & 1.08 \\
\hline UBC 823 & $240-895$ & 7 & 3 & 4 & 57.14 & 0.21 & 2 & 0.84 \\
\hline UBC 826 & $165-665$ & 9 & 4 & 5 & 55.56 & 0.21 & 2.5 & 1.05 \\
\hline UBC 834 & $125-825$ & 6 & 4 & 2 & 33.33 & 0.13 & 1 & 0.26 \\
\hline UBC 846 & $195-1800$ & 11 & 5 & 6 & 54.55 & 0.24 & 4.8 & 1.44 \\
\hline Total & - & 61 & 34 & 27 & - & - & - & - \\
\hline Average & - & 7.63 & 4.25 & 3.38 & 43.94 & 0.18 & - & 0.68 \\
\hline
\end{tabular}

\subsubsection{Polymorphism and variability evaluation}

The relationships among the evaluated cultivars were further illustrated according to similarity coefficient of Jaccard based on SSR and ISSR data (Table 5). The SSR data displayed moderate similarity among the four cultivars ranged from 0.44 to 0.59 . The highest similarity $(0.59)$ was between Hercule and Top cultivar, while the lowest similarity (0.44) was noted between Hosam and Kawamera cultivar. On the other hand, the ISSR data showed the highest similarity (0.85) was between Kawamera and Top cultivars, while the lowest similarity (0.66) was between Hercule and Hosam cultivar. Moreover, the dendrogram of genetic similarity in the SSR marker classified the four cultivars into two main clusters (Fig. 3a). The first one contained only the highest drought- 
tolerant cultivar (Kawamera), while the second one was divided into two sub-clusters, Only more drought-sensitive cultivar (Hosam) was placed in one of them, but the moderate tolerant cultivars (Hercule and Top) gathered in the second subcluster. ISSR marker also grouped the four cultivars into two main clusters (Fig. 3b). The first cluster contained only Hosam cultivar, while the second cluster was divided into two sub-clusters. One of them contained only Hercule cultivar, but the other one joined Kawamera and Top cultivar. These results are consistent with that the SSR marker more efficient and associated with drought tolerance and some agronomic traits (Nachit et al., 2000). Combined SSR and ISSR results showed that the total amplified bands were 81 bands, 42 out of them were polymorphic, with a $51.22 \%$ polymorphism (Table 4). Furthermore, the detected similarity ranged from 0.62 to 0.77 . Like as shown by ISSR, the highest and the lowest

similarity was also between Kawamera and Top cultivars, Hercule and Hosam cultivar, respectively (Fig. 3c). Also, the dendrogram distributed the four cultivars as in the ISSR marker.

The results of molecular analysis, productivity and quality parameters were able to differentiate among all the cultivars according to their drought tolerance capacity.

Table 5. The similarity index among the four cultivars based on SSR, ISSR and combined.

\begin{tabular}{lcccc}
\hline Cultivars & Top & Kawamera & Hercule & $\begin{array}{c}\text { Marker } \\
\text { type }\end{array}$ \\
\hline \multirow{3}{*}{ Kawamera } & 0.53 & & & SSR \\
& 0.85 & & & ISSR \\
Combined
\end{tabular}

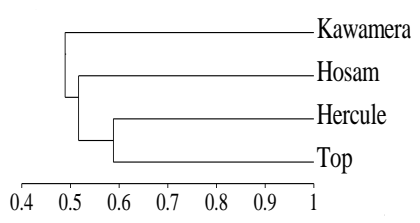

a) SSR

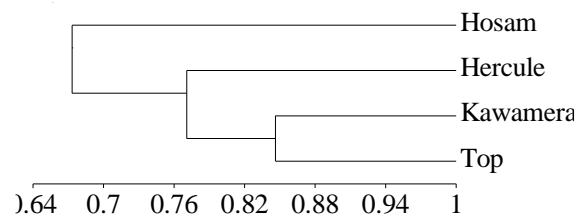

b) ISSR

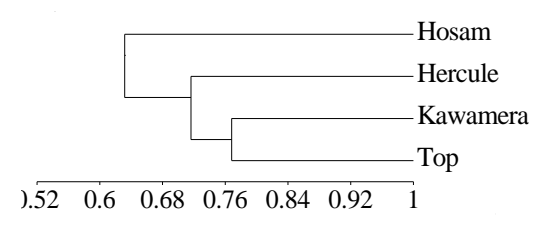

c) Combined

Fig. 3. The dendrograms of genetic similarity among the four sugar beet based on SSR, ISSR marker and combined.

\section{Conclusion}

In the present study, four sugar beet cultivars were evaluated for their performance under drought stress conditions and DNA molecular analysis. Significant differences were observed among them for the studied productivity and quality traits under normal and stressful conditions. Whereas, Kawamera cultivar showed the most superior performance in the studied traits. Moreover, both SSR and ISSR markers successfully differentiated among these cultivars. Furthermore, the SSR markers were more distinguishable according to the PIC value. In addition, they were able to classify the cultivars according to their drought tolerance, where the highest drought-tolerant cultivar (Kawamera) was separated in main cluster. However, the superiority of Kawamera cultivar under drought stress suggested that this cultivar could be used in advanced breeding programs.

\section{Acknowledgements}

This study was supported financially by the Faculty of Agriculture, New Valley University, Egypt.

\section{References}

A.O.A.C. (2005): Association of Official Analytical Chemists. Official Methods of Analysis. 16th ed., Washington, D.C., U.S.A.

Abbasi, Z., Majidi, M.M., Arzani, A., Rajabi, A., Mashayekhi, P., and Bocianowski, J. (2015) 'Association of SSR markers and morphophysiological traits associated with salinity tolerance in sugar beet (Betavulgaris L.)', Euphytica, 205(3), pp. 785-797.

Abdollahi-Mandoulakani, B., Sadigh, P., Azizi, H., Piri, Y., Nasri, S., and Arzhangh, S. (2015) 'Comparative assessment of IRAP, REMAP, 
ISSR, and SSR markers for evaluation of genetic diversity of alfalfa (Medicago sativa L.)', Journal of Agricultural Science and Technology, 17, pp. 999-1010.

Bachmann, K., Blattner, F., Fischer, D., Friesen, N., and Fritsch, R. (2001) 'Molecular markers in Allium: range of application, reliability and taxonomic implications', Acta horticulturae, 546, pp.159-163.

Bashandy, T. and EL-Shaieny, A. (2016) 'Screening of Cowpea (Vigna unguiculata L. Walp) genotypes for salinity tolerance using field evaluation and molecular analysis', Journal of Agricultural Chemistry and Biotechnology, 7(9), pp. 249-255.

Bashandy, T., Hussein, A., Solma, M., Kassab, A., and Hamdon, H. (2020) 'molecular evaluation of three populations of Farafra sheep in comparison to Ossimi and Rahmani sheep breeds', Acta Universitatis Agriculturae et Silviculturae Mendelianae, 68(6), pp. 929-936.

Beckmann, J.S., and Weber, J.L. (1992) 'Survey of human and rat microsatellites', Genomics, 12(4), pp.627-631.

Bogacheva, N.N., Fedulova, T.P., and Nalbandyan, A.A. (2019) 'Innovation methods of beta vulgaris 1. molecular breeding', Rossiiskaia selskokhoziaistvennaia nauka, 2, pp. 15-18.

Brar, N.S., Dhillon, B.S., Saini, K.S., and Sharma, P.K. (2015) 'Agronomy of sugar beet cultivation-A review', Agricultural Reviews, 36(3), pp. 184-197.

CCSC (2010) Sugar Crops Council. Ann. Report, Ministry of Agric., Egypt. (In Arabic).

Chaves, M.M., Maroco, J.P., and Pereira J.S. (2003) 'Understanding plant responses to drought from genes to the whole plant', Functional Plant Biology, 30(3), pp. 239-64.

Farooq M., Wahid, A., Kobayashi, N., Fujita, D., and Basra, S.M.A. (2009) 'Plant drought stress: effects, mechanisms and management', Agronomy for Sustainable Development, 29, pp. 185-212.

Foroozesh, P., Heravan, E.M., Bihamta, M.R., Taleghani, D.F., and Habibi, D. (2012) 'Physiological evaluation of sugar beet genotypes under drought stress', AmericanEurasian Journal of Agricultural and Environmental Sciences, 12(6), pp. 820-826.
Fufa, H., Baenziger, P.S., Beecher, B.S., Dweikat, I., Graybosch, R.A., and Eskridge K.M. (2005) 'Comparison of phenotypic and molecular marker-based classifications of hard red winter wheat cultivars', Euphytica, 145(1), pp. 133146.

Ghislain, M., Zhang, D., Fajardo, D., Huamann, Z., and Hijmans, R.H. (1999) 'Marker-assisted sampling of the cultivated Andean potato Solanum phureja collections using RAPD markers', Genetic Resources and Crop Evolution, 46(6), pp. 547-555.

Gomez, K.A., and A.A. Gomez, (1984) 'Statistical procedures for agricultural research', $2^{\text {nd }} e d$. John Wiley and Sons, New York.

Hamed, L. M.M., and Emara, E.I.R. (2019) 'Response of some sugar beet varieties to water stress', Misr Journal of Agricultural Engineering, 36(1), pp. 217- 238.

Hamza, H., Ben Abederrahim, M. A., Elbekkay, M., and Ferchichi, A. (2013) 'Comparison of the effectiveness of ISSR and SSR markers in determination of date palm (Phoenix dactylifera L.) Agronomic traits', Australian Journal of Crop Science, 7(6), pp. 763-769.

Hartl, D.L., and Clark, A.G. (1997) 'Principles of population genetics', $3^{\text {rd }}$ ed. Sunderland, Massachsetts: Sinauer Associates, 163.

ICUMSA (2007) 'The determination of the polarisation of sugar beet by the macerator or cold aqueous digestion method using aluminium sulphate as clarifying agent official', In: ICUMSA Method book, eds. International Commission for Uniform Methods of Sugar analysis, Method GS6-3, Dr. Albert Bartens $\mathrm{KG}$, Berlin.

Innan, H., Terauchi, R., and Miyashi-ta, N.T. (1997) 'Microsatellite polymorphism in natural populations of the wild plant Arabiodopsis thailiana', Genetics, 146(4), pp. 1441-1452.

Izzatullayeva, V., Akparov, Z., Babayeva, S., Ojaghi, J., and Abbasov, M. (2014) 'Efficiency of using RAPD and ISSR markers in evaluation of genetic diversity in sugar beet', Turkish Journal of Biology, 38(4), pp. 429-438.

Jaccard, P. (1908) 'Nouvelles recherches sur la distribution florale', Bulletin de la Société vaudoise des sciences naturelles, $44, \mathrm{pp} .223$ 270. 
Jozi M., and Zare Abyane, H. (2015) 'Effects of nitrogen fertilizer and deficit irrigation on quantitative and qualitative traits of sugar beet', Journal of Sugar Beet, 31(2), pp. 141-156.

Khazaie, H.R., Sabet-Teimouri, M., Najafi, F. (2007) 'Investigation on yield and quality of isabgol (Plantago ovata L.) under different irrigation regimes and seeding rates', Iranian Journal of Field Crops Research, 5(1), pp. 7784.

Khozaei, M., Haghighi, A.A.K., Parsa, S.Z., Sepaskhah, A.R., Razzaghi, F., Yousefabadi, V.A., and Emam, Y. (2020) 'Evaluation of direct seeding and transplanting in sugar beet for water productivity, yield and quality under different irrigation regimes and planting densities', Agricultural Management, 238, pp. 106230.

Mahmoodi, R., Maralian, H., and Aghabarati, A. (2015) 'Effects of limited irrigation on root yield and quality of sugar beet (Beta vulgaris L.)', International Journal of Irrigation and Water Management, 2(10), pp.1-4.

Moosavi, S.G.R., Ramazani, S.H.R., Hemayati, S.S., and Gholizade, H. (2017) 'Effect of drought stress on root yield and some morphophysiological traits in different varieties of sugar beet (Beta Vulgaris L.)', Journal of Crop Science and Biotechnology, 20(3), pp. 167-174.

Nachit, M.M, Monneveux, P., Sorrells, M.E., Royo, C., Fonzo, N., and Araus, J.L. (2000) 'Relationship of dry-land productivity and drought tolerance with some molecular markers for possible MAS in durum (Triticum turgidum L. var. durum) ', CIHEAM-Options Mediterranean's, 40, pp. 203-206.

Nourjou, A. (2008) 'The effect of water deficit on yield and yield components of sugar beet and water productivity', Iranian Journal of Irrigation and Drainage, 2(1), pp. 31-42.

Powell, W., Morgante, M., Andre, C., Hanafey, M., Vogel, J., Tingey, S., and Rafalski, A. (1996) 'The comparison of RFLP, RAPD, AFLP and SSR (Microsatellite) markers for germplasm analysis', Molecular Breeding, 2(3), pp. 225238.

Prevost, A., and Wilkinson, M.J. (1999) 'A new system of comparing per primers applied to ISSR fingerprinting of potato cultivars', Theoretical and Applied Genetics, 98(1), pp. 107-112.
Rawat, A., Barthwal, S., and Ginwal, H.S. (2014) 'Comparative assessment of SSR, ISSR and AFLP markers for characterization of selected varieties of Himalayan Chir pine (Pinus roxburghii Sarg.) based on resin yield', Silvae Genetica, 63(3), pp. 94-108.

Reddy, M.P., Sarla, N., and Siddiq, E.A. (2002) 'Inter simple sequence repeat (ISSR) polymorphism and its application in plant breeding', Euphytica, 128(1), pp. 9-17.

Ren, J., Dai, W.R., Xuan, Z.Y., Yao, Y.A., Korpelainen, H., and Li, C.Y. (2007) 'The effect of drought and enhanced UV-B radiation on the growth and physiological traits of two contrasting poplar species', Forest Ecology and Management, 239(1-3), pp. 112-119.

Sharma, S.N., Kumar, V., and Mathur, S. (2009) 'Comparative analysis of RAPD and ISSR markers for characterization of sesame (Sesam umindicum L.) varieties', Journal of Plant Biochemistry and Biotechnology, 18(1), pp. 3743.

Sugar Crops Council (2018) Sugar Crops and Sugar Production, Arabic Ed.

Taški-Ajduković, K., Nagl, N., Ćurčić, Ž., and Zorić, M. (2017) 'Estimation of genetic diversity and relationship in sugar beet pollinators based on SSR markers', Electronic Journal of Biotechnology, 27, pp. 1-7.

Tatikonda, L., Wani, S.P., Kannan, S., Beerelli, N., Sreedevi, T.K., Hoisington, D.A., Devi, P., and Varshney, R.A. (2009) 'AFLP-based molecular characterization of an elite germplasm collection of Jatropha curcas L., a biofuel plant', Plant Sciences, 176(4), pp. 505-513.

Weising, K., Kaemmer, D., Weigand, F., Epplen, J.T., and Kahl, G. (1992) 'Oligonucleotide fingerprinting reveals various probe dependent levels of informativeness in chickpea (Cicer arietinum)', Genome, 35(3), pp. 436-442.

Wu, G.Q., Feng, R.J., and Shui, Q.Z. (2016) 'Effect of osmotic stress on growth and osmolytes accumulation in sugar beet (Beta vulgaris L.) plants', Plant, Soil and Environment, 62(4), pp. 189-194.

Zietkiewicz, E., Rafalski, A., and Labuda, D. (1994) 'Genome fingerprinting by simple sequence repeat (SSR)-anchored polymerase chain reaction amplification', Genomics, 20(2), pp. 176-183. 